\title{
THE IMPACT OF THE FINANCIAL TRANSACTION TAX ON THE LIQUIDITY PREMIUM OF RETAIL CUSTOMERS' BANK DEPOSITS ${ }^{1}$
}

\begin{abstract}
The paper aims to describe how the amount of retail customers' bank deposits has changed as a result of launching the financial transaction tax in Hungary. The liquidity premium related to all bank deposits offered by Hungarian banks will be analysed and its amount will be calculated from the transfer costs on the supply side. The objective of the research is to measure liquidity premium at sector level. When analysing the liquidity premium, both the size of the invested amount and duration of the deposit are tackled. Since the size of liquidity premium may considerably affect competition on the market, the paper tries to model this relationship and estimate the value of the corresponding parameters.
\end{abstract}

Keywords: transaction tax, bank deposit, liquidity, interest, competition

\section{Introduction}

The paper aims to model the relationship between the strength of market competition and the effect of launching the financial transaction tax in Hungary. The financial culture of private individuals may be regarded to be at a low level almost in each age group in Hungary. Hungarian retail customers seem to lack information on financial issues [see Csiszárik-Kocsir, 2013; and the findings of research by MNB-Pénziránytü-GFK]. One of the prerequisites of making adequate financial decisions, as well as, adapting to the market conditions is that customers should be able to react to changes by undertaking relatively low transaction costs. In case of bank deposits this is closely related to the costs of 
changing banks, the considerable proportion of which is made up of transfer costs. Therefore, it is utmost important to examine how the upcoming transfer costs are formed, as well as, restrict flexible adaptation and competition on the market as a result of launching the financial transaction tax. In compliance with it, regarding the whole retail deposit market - with different amounts and duration - the lowest amount of liquidity interest premium will be defined, which is necessary to switch banks to offset its (directly upcoming) monetised costs.

\section{Theoretical background}

In addition to market mechanisms and the direct effects of the financial crisis, the Hungarian deposit market is also influenced by the economic policy, governmental measures and regulation changes related to state's risk management policy. Instead of analysing the effects and efficiency of these measures, we primarily focus on characterising the financial culture on the deposit market. As it is generally accepted that the regulations affecting the whole sector - including the launch of the financial transaction tax - may be regarded as competitively neutral [Várhegyi, 2011], it is not necessary to analyse the different segments of financial intermediaries based on certain criteria.

When pricing deposit products, banks mainly apply the micro-economic approach, or cost-based pricing or either of these combinations [Bankárképzö, 2008]. Using the micro-economic approach banks primarily form their pricing strategy taking their competitors into consideration. This approach is based on decisive factors of the market forces, the strength of the competition, the market structure and the flexibility of the customers. The appearance of the liquidity premium is able to directly define the price flexibility by offsetting the costs deriving from the illiquidity of flexibility. In the course of cost-based pricing the bank mainly focuses on its prospective incomes and expenses, taking into account the corresponding relationships at macro-economic and consumption level, as well as, the future trends and expectations.

There are two views on analysing competition in banking in scientific literature. According to the traditional view, the analytical methods created for corporate clients based on symmetric information focusing on the efficiency of production may also be applied to the banking sector. Whereas in models focusing on bank's market position, banks intentionally keep the transfer costs at a relatively high level distorting the savings and investment decision of the lenders and creditors [Várhegyi, 2003; Silva, Lucindab, 2017]. Costs deriving from the lack of competition emerge as social (welfare) loss, which may add up to a considerable amount [Oxenstiema, 1999].

To measure market intensity the most popular indicators refer to the market structure and its profitability. Their application is based on the assumption that on an oligopolistic market the dominant market players may achieve a significantly higher profit than on the competitive market [Gém, 2008]. According that e.g. the 
evidence of Malaysian commercial banks experienced increased concentration coupled with lower competition [Ab Rahim, 2016]. In addition to the so called structure-conduct-performance (SCP) models, in order to describe the intensity of competition, banks' pricing behaviour is also investigated focusing on the size, directions and trends of customer mobility.

Customers' interest sensitivity, however, may be a significant parameter for the supporters of both the micro-economic approach and the cost-based approach. Interest sensitivity is mainly affected by customers' preferences and the cost of switching banks [Bankárképzö, 2008]. The price flexibility in demand for deposits may deteriorate due to the costs of changing banks, which will be taken into consideration by banks when shaping their pricing strategy [Zephirin, 1994]. However, the costs of switching banks may be difficult to measure because they do not only include tangible costs in the form of money but they also contain certain alternative costs (e.g. time for comparing deposit products, educational expenses), and are characterised by some psychological changes in customers' usefulness (e.g. diminishing comfort feeling) [Gondat-Larralde, Nier, 2006].

One method to analyse the costs of switching banks is to interpret those as transfer costs. In general, in case of deposits, transfer costs may be divided into two main groups. If the given costs do not involve financial risk management, we refer to them as account management fees, whereas in the other case risk (loss) management fees. During the transaction process, there may also emerge some transfer costs, but as they do not refer to any loss against, they may be regarded as management fees [Kállay, 2005].

\section{Empirical analysis}

Empirical analysis aims to determine the liquidity interest premium imposed on retail customers' bank deposits. The analysis also involves the optimal bank account schemes attached to deposits by banks. The paper highlights the relationships between the amounts of the deposited sum, the duration of the deposits and the amount of the liquidity premium. The analysis contains the following areas:

- Direct banking products;

- Products for retail customers;

- "Pure deposit products" excluding mixed ones;

- Forint-based products;

- Short-term deposits (duration less than a year);

- Account packages for special customer segments (e.g. students) have been excluded;

- "Premium banking" offers have not been examined;

- Offers other than "standard" (customized offers) haven't been tackled.

Decision-making savers (retail customers) are supposed to have some financial rationality and be adequately informed, i.e. have the ability to gather the necessary 
information and interpret it correctly. When choosing the ideal account package, costs that can be measured directly in monetised form have been taken into account.

With reference to the described research field, we investigated offers provided by the Hungarian banking system on $15^{\text {th }}$ March 2013 . Based on the formerly described criteria those involve 25 commercial banks and their retail deposit products. When determining the costs of the individual accounts we have disregarded the requirements for special offers, except cases in which these requirements could have been automatically met (e.g. benefits depending on the size of savings. When determining the amount of costs related to changing banks and hat of the liquidity premium we first started with the money transfer fee. In case of account management fees we have disregarded account termination fess and the penalty fee imposed in case of offending the minimum account keeping period (their effect on the sector seemed to be negligible, it was apparent only in few banks). Effects related to delays in account termination have been considered by calculating one more month account management fee in contrast with the planned duration.

We have examined the relationships of the factors shaping the liquidity premium with reference to two durations: two and six months, as well as, three-three time deposits: one, two and twenty million HUF (six scenarios altogether). First we collected the characteristics, fees, the method of how fees are set with a special focus on payment transfer fees (one-off transfer, transfer to outside partner) and account management fee of all account packages of all banks that may be important for decision-making. Then we computed the cost of changing banks for each account package for all the six scenarios. Based on the fees in case of each bank we selected the optimal account package for time deposits. We calculated the value of the liquidity premium in case of each bank on the basis of the costs, the deposited sum and duration for all the six scenarios. First, we analyse the distribution of liquidity premium for the six scenarios, then compare the characteristics and differences in case of the individual scenarios.

\section{Time deposit: one million HUF for two months}

Figure 1 demonstrates changes in the liquidity premium for 24 banks (in random order).

The average value of the liquidity interest premium is 1.88 point, while the estimated value of the mode is 1.2 ; that of the median is 1.6 . The data show a significant range, the value of the range is 0.79 ; that of the relative range is $42.1 \%$. Arranging the data according to frequency occurrence we may draw up a histogram which shows their distribution (Figure 2).

As presented by the histogram, the value of the liquidity premium indicates a strong asymmetry on the right. 


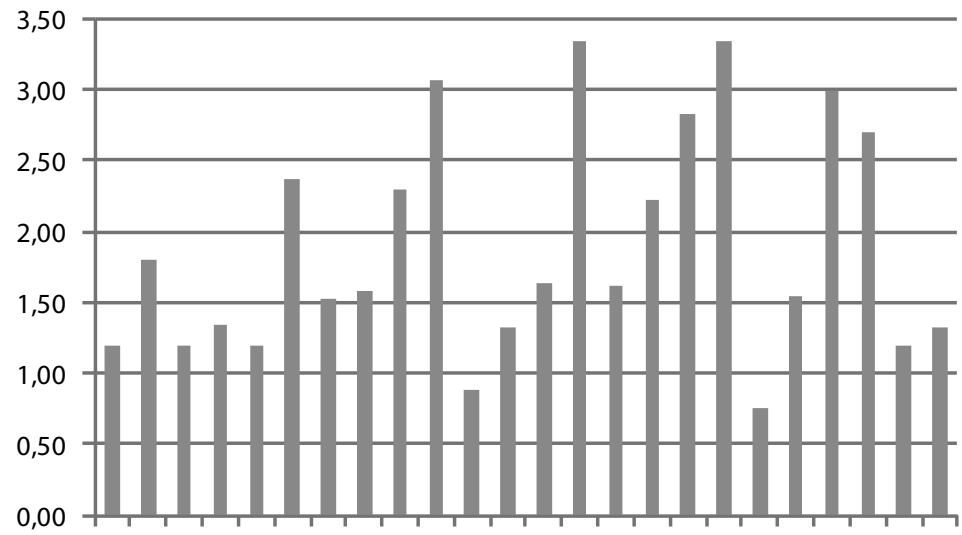

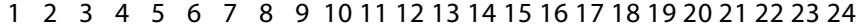

Figure 1. Changes in the liquidity premium (1 million HUF, 2 months)

Source: own design.

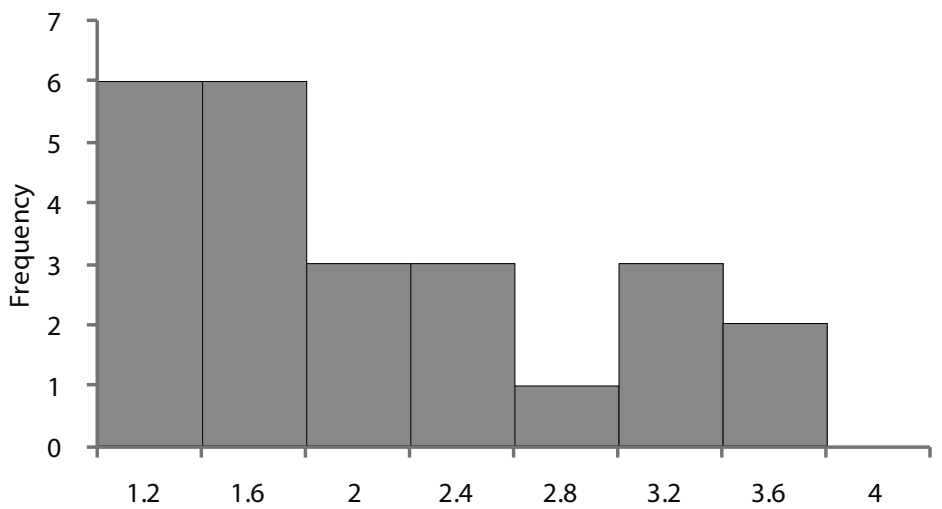

Figure 2. The distribution of the interest premium (1 million HUF, 2 months)

Source: own design.

\section{Time deposit: one million HUF for six months}

The average value of the liquidity premium is only 0.91 , which is much lower than that of the two-month time deposit. The estimated value of the mode is 0.4 , the median amounts to 0.4 . These data show a significant range with 0.53 , while the relative range totals $58.5 \%$ (Figure 3 ). 


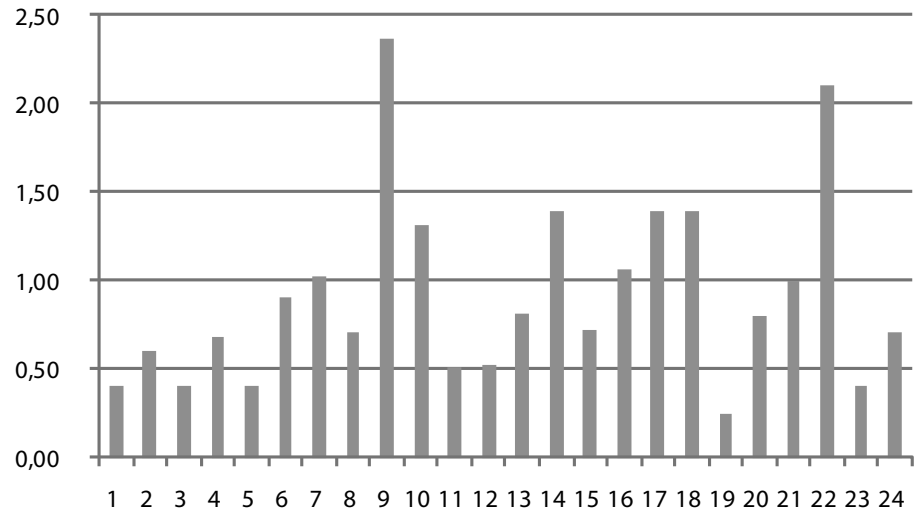

Figure 3. The distribution of the interest premium (1 million HUF, 6 months)

Source: own design.

As the histogram demonstrates, asymmetry on the left was a lot lower than the increase of the two-month deposit. In the case of the eight banks the value of the interest premium ranges between 0.5 and 0.9 (Figure 4).

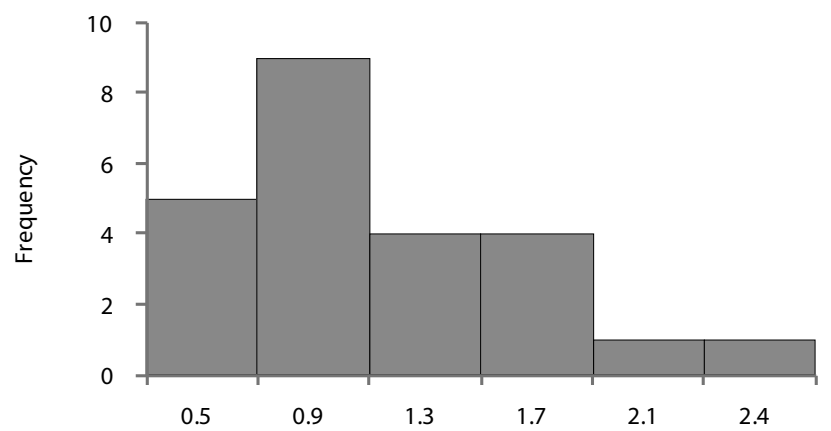

Figure 4. The distribution of the interest premium (1 million HUF, 6 months)

Source: own design.

\section{Time deposit: five million HUF for two months}

In case of this deposit there is a sharp drop in the interest premium (Figure 5). This results from the six thousand HUF upper limit of the financial transaction tax, which is also used by the price setting practice of banks when determining the transfer fees. In case of three million HUF when the transaction tax is calculated with $0.2 \%$ fee, the maximum transaction tax shall be paid Therefore, in case 
of five million HUF, this sum would be exceeded; as a result, its relative amount will decrease.

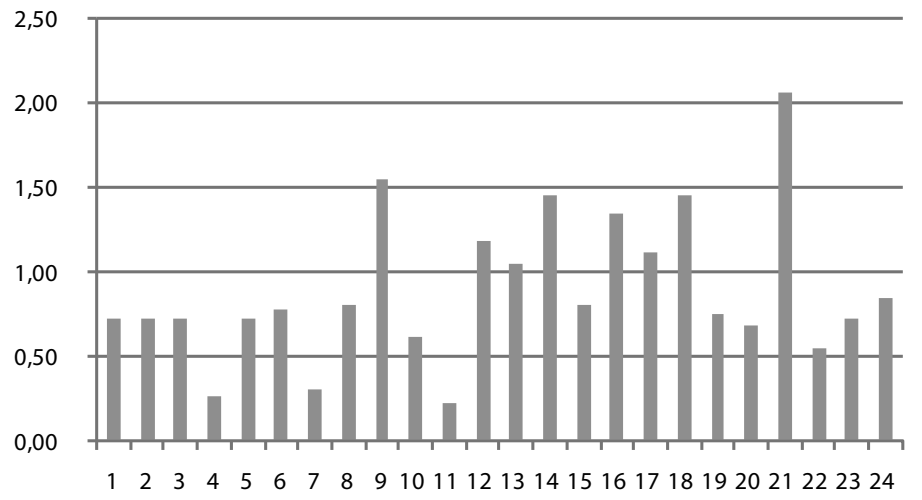

Figure 5. The distribution of interest premium (5 million HUF, 2 months) Source: own design.

The average value of the liquidity interest premium is 0.89 , which is a lot lower than that of the one million HUF time deposit. The estimated value of the mode is 0.72 ; that of the median amounts to 0.76 . Also in this case data show a significant range, where the value of the range is 0.44 and that of the relative range is $49.1 \%$ (Figure 6).

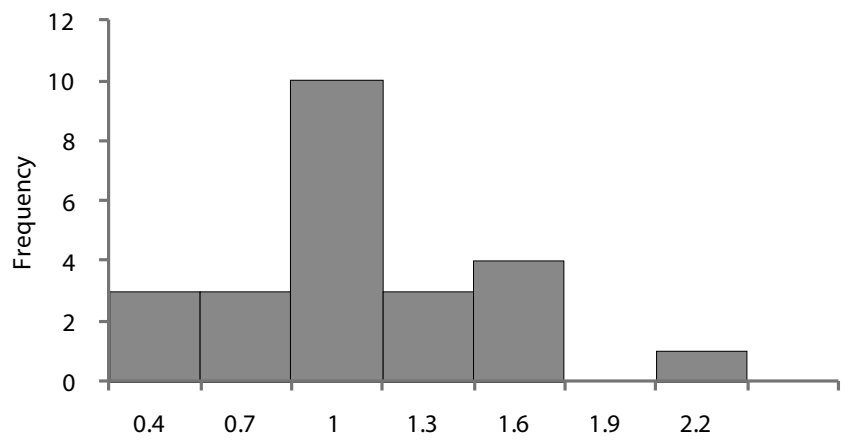

Figure 6. The distribution of the interest premium (5 million HUF, 2 months)

Source: own design.

In this case the distribution of the interest premium hardly diverges from being symmetric; it only indicates a weak asymmetry on the left. 


\section{Time deposit: five million HUF for six months}

In case of six-month duration, the average interest premium has decreased to $30 \%(0.33)$ in contrast with the two-month deposit of the same amount (Figure 7). The value of the mode and that of the median seem to be much lower $(0.28$ and $0.24)$. Similar to the two-month deposit the range of the interest premiums is significant (44.86\%).

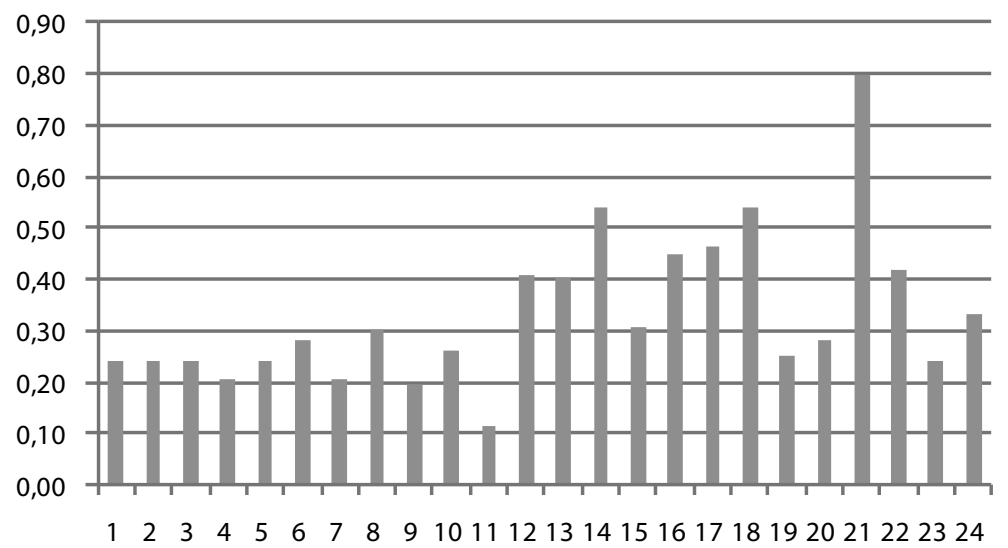

Figure 7. The distribution of the interest premium (5 million HUF, 6 months)

Source: own design.

The range that proved to be almost symmetric has significantly changed in case of the six month duration with asymmetry on the left (Figure 8).

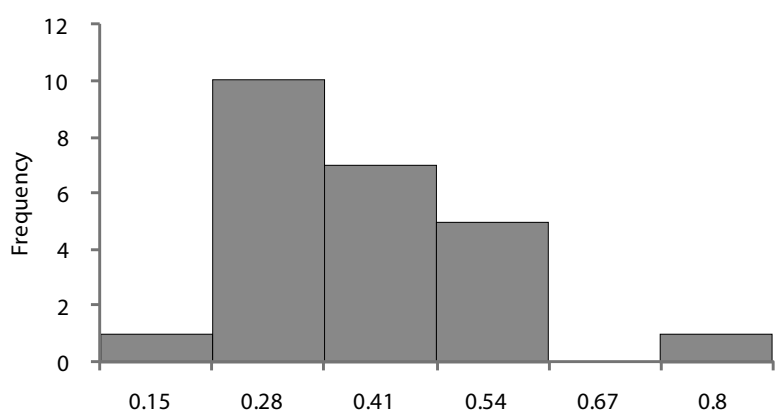

Figure 8. The distribution of the interest premium (5 million HUF, 6 months)

Source: own design. 


\section{Time deposit: twenty million HUF for two months}

In case of the twenty million HUF time deposit it was questionable how significant the relative price drop might be due to the maximum amount of the transaction tax in case of three million HUF if the five million HUF deposit also exceeds the limit. We have found that average value has decreased to $30 \%(0.31)$. The value of the mode and that of the median is about 0.18 . However, the relative range size has doubled (81.17\%) compared with the five million HUF deposit (Figure 9).

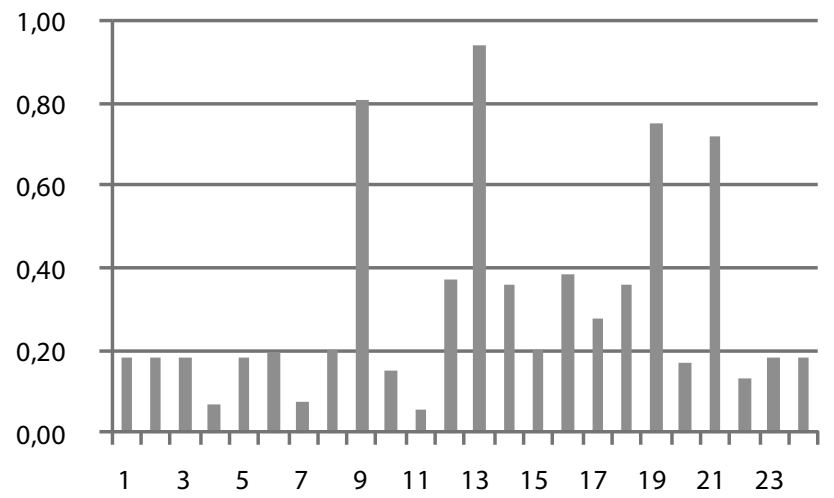

Figure 9. The distribution of the interest premium (20 million HUF, 2 months)

Source: own design.

The value of the liquidity interest premium demonstrates a significant asymmetry on the right. Its most frequent value ranges between 0.1 and 0.25 (Figure 10).

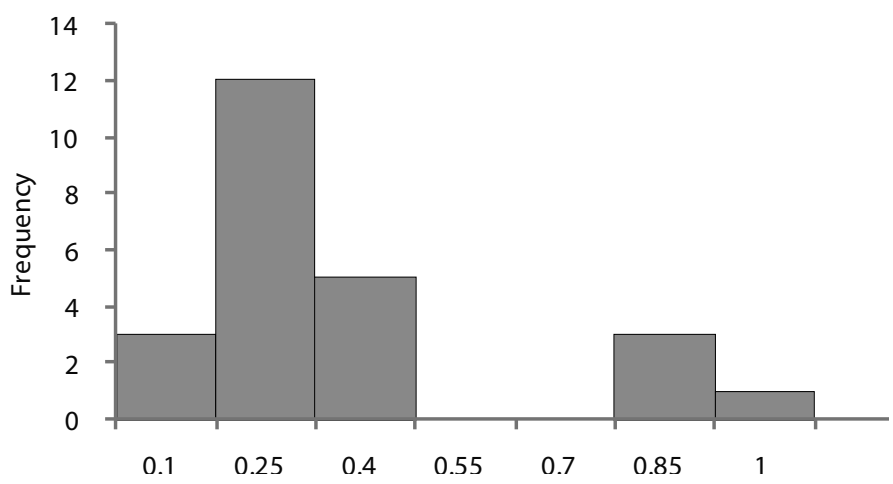

Figure 10. The distribution of interest premium (20 million HUF, 2 months)

Source: own design. 


\section{Time deposit: twenty million HUF for six months}

The average liquidity interest premium appears to be the lowest $(0.11)$ in case of the highest amount of deposit and longest duration (Figure 11). The value of the median is 0.072 , while that of the estimated range is only 0.06 . The range of the data was considerable $(71.88 \%)$.

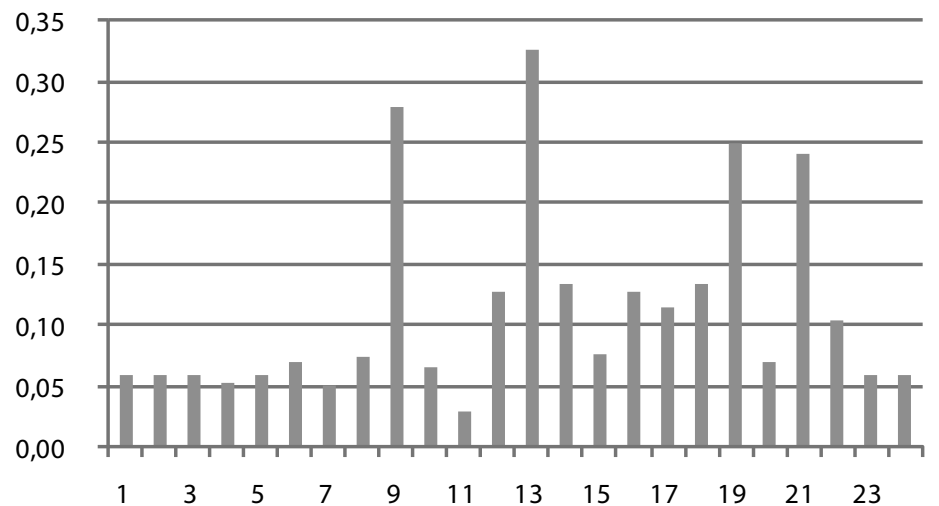

Figure 11. The distribution of the interest premium (20 million HUF, 6 months) Source: own design.

The distribution of the interest premiums demonstrates a clear-cut, strong asymmetry on the left but the highest interest premium remained below 0.33 (Figure 12).

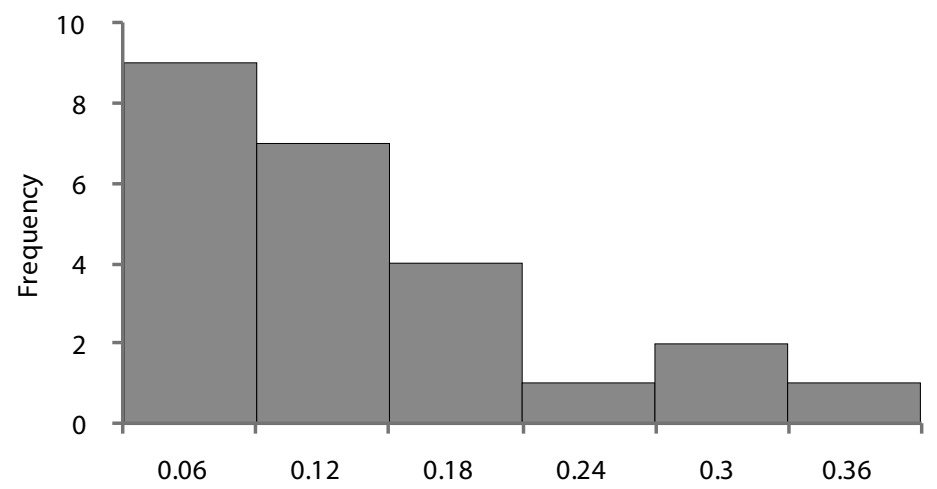

Figure 12. The distribution of the interest premium (20 million HUF, 6 months) Source: own design. 


\section{Conclusions}

In conclusion we may assume that the launch, size and calculation method of the financial transaction tax considerably affects the payment transfer fees and through them the average sectoral value of the liquidity interest premiums. The value of the liquidity premium gradually decreases in compliance with the size and amount of the deposited sum which may be due to the upper limit of the transaction tax and "spreading" the costs in time. The absolute size of the interest premium is said to be significant in each case compared to the general sectoral deposit interest rate level at the time of the research. This makes it more difficult and financially irrelevant to switch banks. Nevertheless, there has been a considerable distribution with reference to the interest premium among banks, which was also indicated by the significant value of the relative range in case of the examined situations. Almost in each case the distribution of the interest premium showed asymmetry on the left suggesting that there were several banks with a lower interest premium than the average.

The distinctly high value of the liquidity premium reduces the intensity of competition, because it makes it irrelevant to change banks, as a result, it does not put a strain on banks to provide competitive offers. Another contributing factor is the traditionally record low interest rate in Hungary. In case of low interest rate it is more difficult to offset the relatively high interest premium. This would lead to a multiple interest on deposits compared to the market interest rate. It may be stated that the introduction of the financial transaction tax has sharply reduced the liquidity of bank deposits and has heavily restricted competition.

As a result, in recent years Hungarian households have "ignored" this form of investment (see Figure 13). Although by the end of 2016, the value of financial assets of Hungarian household has exceeded 40.000 billion HUF ( $+40 \%$ compared to 2010), the stock of bank deposits has remained practically unchanged [Boldizsár, Kékesi, 2017].

It means, recent years have brought changes in the composition of assets held by households. The stock of government securities has increased almost six-fold since the middle of 2010. Besides government bonds, treasury bills are another popular investment form among households. This trend is due mainly to low interest rates in recent years (see Figure 14), but also to high risk aversion [Ministry for National Economy, 2017]. 

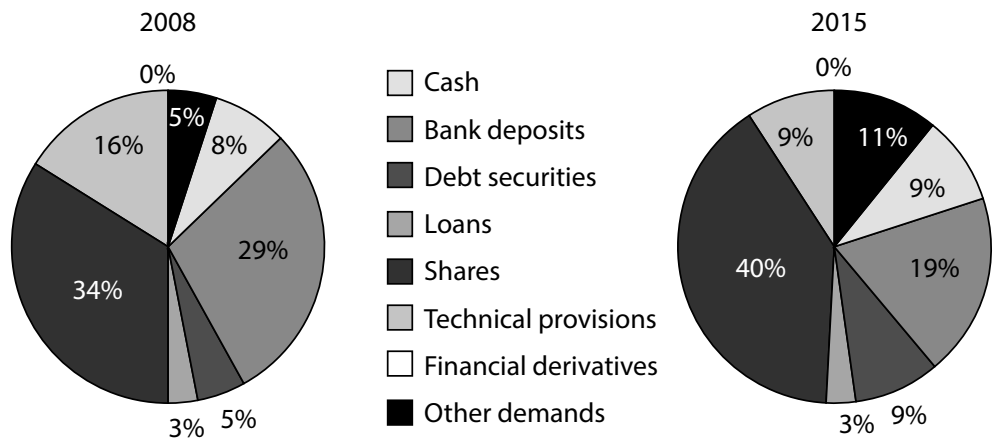

Figure 13. Financial assets of Hungarian households (\%)

Source: Magyar Nemzeti Bank (Hungarian National Bank).

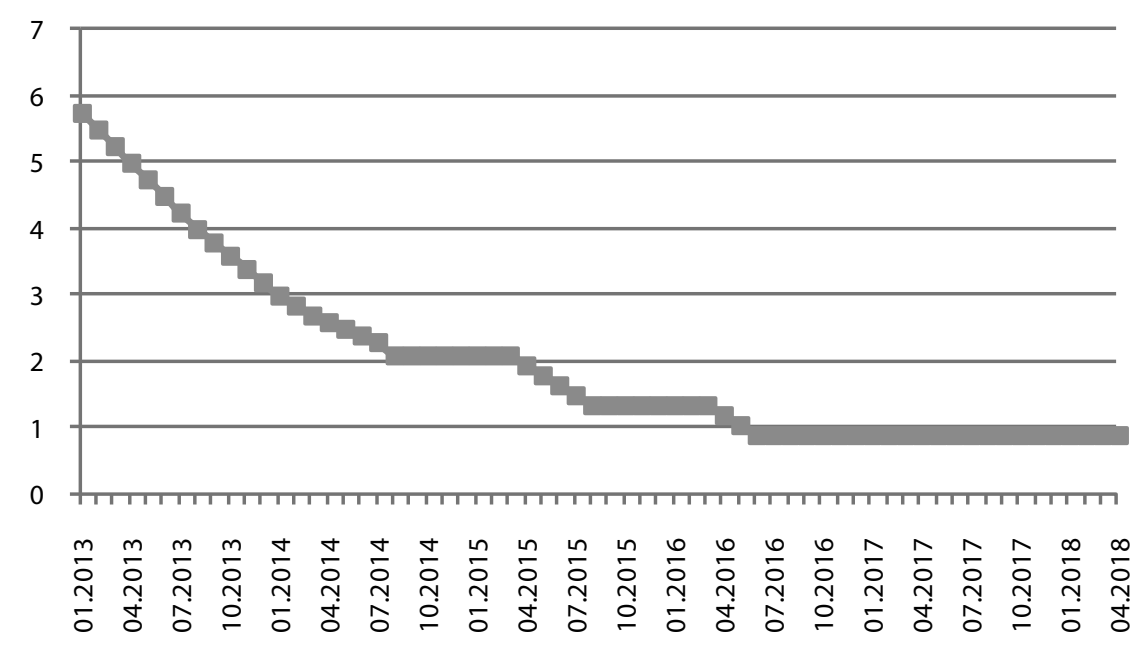

Figure 14. Central Bank Base Rate (\%) 2013-2018

Source: Magyar Nemzeti Bank (Hungarian National Bank).

\section{References}

Ab Rahim R. (2016), Does Competition Foster Efficiency? Empirical Evidence from Malaysian Commercial Banks, Asian Academy of Management Journal of Accounting and Finance, 12(1), 1-23.

Bankárképző (2008), Tanulmány a banki betéti szolgáltatások árképzési gyakorlatáról magyarországi és nemzetközi viszonylatban [Paper on the price setting practice of bank deposits 
in Hungary and international comparison], http:/www.pszaf.hu/data/cms1571949/Bank rk__pz___lakoss__gi_bet_ti___rk__pz__s___tanulm_ny_080829.pdf [accessed $6^{\text {th }}$ May 2013].

Boldizsár A., Kékesi Zs. (2017), Soha nem rendelkeztünk még ennyi megtakaritással [Net household savings at a record high in Hungary], Magyar Nemzeti Bank, https://www. mnb.hu/letoltes/boldizsar-anna-kekesi-zsuzsa-soha-nem-rendelkeztunk-meg-ennyi-megtaka-mnbhonlapra.pdf [accessed $10^{\text {th }}$ May 2018].

Csiszárik-Kocsir Á. (2013), A huszonéves fiatalok pénzügyi alapfogalom ismerete egy kérdöives kutatás eredményeinek tükrében [The knowledge of financial concepts among young people over 20 as reflected by a survey]. „A felfedező tudomány” c. konferencia konferenciakötete, MTA VEAB (megjelenés alatt), https://kgk.sze.hu/images/dokumentumok/VEABtanulmanyok/csiszarik_kocsir_agnes.pdf [accessed $8^{\text {th }}$ May 2018].

Gém E. (2008) (ed.), A versenyintenzitás mérése a retail banki szolgáltatások piacán [Measuring the intensity of competition on the retail banking market], Kutatási jelentés, KOPINT Konjunktúra Kutatási Alapítvány [Research report]. http://www.gvh.hu/domain2/files/ modules/module25/56811940C2313AF1.pdf [accessed 6 ${ }^{\text {th }}$ May 2013].

Gondat-Larralde C., Nier E. (2006), Switching Costs in the Market for Personal Current Accounts: Some Evidence for the United Kingdom, Working Paper No. 292, Bank of England.

Kállay L. (2005), Tranzakciós költségek: optimum, méretgazdaságosság, egyensúly, Doktori disszertáció [Transaction costs: optimum, economies of scale, equilibrium. PhD dissertation], http://doktori.bibl.u-szeged.hu/322/1/de_2932.pdf [accessed $6^{\text {th }}$ May 2013].

Ministry for National Economy (2017), Savings and Assets of Households Continued to Increase, http://www.kormany.hu/download/a/d9/11000/Outlook_2017_25_h\%C3\%A9t\%20 $\% 28$ Savings $\% 20$ and $\% 20$ assets $\% 20$ of $\% 20$ households $\% 20$ continued $\% 20$ to $\% 20$ increase $\% 20 \mathrm{in} \% 20$ Hungary\%29\%20.pdf [accessed $12^{\text {th }}$ May 2018].

MNB-Pénzügyiránytü-GFK (2011), Pénzügyi kultúra alapkutatás [Fundamental research on financial culture], Magyar Nemzeti Bank, http://www.mnb.hu/Root/MNB/Sajtoszoba/mnbhu_pressreleases/mnbhu_pressreleases_2011/mnbhu_kozlemeny_20110407 [accessed $2^{\text {nd }}$ May 2013].

Oxenstiema G. (1999), Testing for Market Power in the Swedish Banking Oligopoly, http:// www.kkv.se/upload/filer/forskare-studenter/projekt/1997/proj130-1997_4.pdf [accessed $6^{\text {th }}$ May 2013].

Silva M.O., Lucindab C.R. (2017), Switching Costs and the Extent of Potential Competition in Brazilian Banking, EconomiA, 18, 117-128 https:/www.sciencedirect.com/science/article/pii/S1517758016301126 [accessed $13^{\text {th }}$ May 2018].

Várhegyi É. (2003), Bankverseny Magyarországon [Banking competition in Hungary], Közgazdasági Szemle [Economic Review], L. évf., December, 0(12), 1027-1048.

Várhegyi É. (2011), A magyar bankszektor szabályozása és versenyhelyzete a válságban [The regulation and competitiveness of the Hungarian banking sector during the crisis] [in:] Valentiny Pál-Kiss Ferenc László-Nagy Csongor István: Verseny és szabályozás 2011. [Competition and regulation] (pp. 210-238), MTA KRTK Közgazdaság-Tudományi Intézet.

Zephirin M.G. (1994), Switching Costs in the Deposit Market, The Economic Journal, 104(423), 455-461. 